\title{
PROBLEMATIKA ANAK ANGKAT DALAM PERSPEKTIF HUKUM ISLAM
}

\author{
MISNAN \\ Kepala Kantor Urusan Agama Kecamatan Binjai Utara Kotamadya Binjai \\ Email : misnanma2@gmail.com
}

\begin{abstract}
For households that do not have children, an alternative that is taken by husband and wife is to adopt a child who is better known as an adopted child. Adopting a child is not something that is forbidden in Islamic teachings because the Messenger of Allah himself in his life had adopted a child. This article discusses various problems surrounding adopted children from the perspective of Islamic law. The discussion begins with an explanation of the meaning of adopted children, the basis of arguments about the problems of adopted children, problems related to adopted children and analysis of the problems of adopted children in the perspective of maqashid. This article finds that adoption has strong arguments, but in doing so one should pay attention to various aspects so as to ensure benefit for the adopted child and the parents who adopt him/her.
\end{abstract}

Keywords: adoption, adopted Children, islamic law

\section{A. Pendahuluan}

Keluarga yang sempurna adalah keluarga yang memiliki anak atau keturunan. Bahkan di dalam menafsirkan Surah Ar-Rüm ayat 21, kata 'rahma' adalah dalam arti memiliki keturunan. Namun dalam kenyataannya, tidak setiap keluarga dapat dengan mudah memiliki anak, dengan berbagai macam sebab dan alasannya. Bahkan sampai berpuluh Tahun usia mereka, seorang anak tidak juga terlahir dari rahim isterinya.

Persoalan yang seperti ini biasanya suami isteri tersebut mencari solusi dengan mengangkat anak, baik yang ada hubungan keluarga dengan mereka, atau pun tidak. Misalkan ada seorang kakak yang setelah puluhan Tahun menikah tidak juga diberi keturunan, maka adiknya yang ternyata diberikan banyak rejeki anak, mengikhlaskan salah seorang anak yang baru dilahirkannya untuk diasuh atau diadopsi oleh kakaknya. Kadangkala juga, ada keluarga yang mengangkat anak dari rumah sakit, yang diketahui setelah dilahirkan orang tua anak tersebut tidak mempunyai biaya untuk menebusnya, maka mereka pun akan menebusnya dengan perjanjian anak tersebut diberikan kepada mereka untuk diadopsi menjadi anak angkat. Kasus ini biasanya akan diketahui nasab keturunan ayah dan ibunya. 
Tidak jarang juga terjadi, orang yang mengadopsi anak bukan karena mereka tidak memiliki anak, namun mungkin karena sifat kasih sayang dan perhatian mereka melihat ada anak yang terlantar dibuang ibunya saat masih bayi di jalanan atau kasus-kasus lainnya, lalu dipungut dia untuk diasuh dan diadopsinya agar terjamin kehidupan dan pendidikannya. Biasanya, kasus seperti ini tidak akan diketahui siapa sebenarnya nasab dari ayah dan ibunya utamanya dari anak-anak yang terlahir lalu dibuang oleh ibu yang tidak bertanggung jawab. ${ }^{1}$

Makalah ini membahas tentang problematika anak angkat utamanya dari mereka yang tidak memiliki hubungan keluarga atau darah tentang berbagai hal yang terkait seperti masalah perwalian, pewarisan dan pergaulan di dalam rumah, karena pada hakikatnya mereka bukanlah mahram, artinya mereka adalah ajnabi atau orang asing yang dapat menikah orang tua dan anak angkatnya.

\section{B. Pengertian Anak Angkat}

Anak angkat disebut juga anak adopsi. Kata Adopsi sendiri berasal dari Bahasa Inggris adopt yang bermakna mengambil, mengangkat dan memungut. Dalam Kamus Besar Bahasa Indonesia anak angkat adalah anak orang lain yang diambil dan disahkan sebagai anaknya sendiri. ${ }^{2}$ Secara terminologi, menurut ulama fikih Mahmūd Syalțut, beliau membedakan dua macam pengertian anak angkat, yaitu :

1. Pernyataan seseorang terhadap anak yang diketahui bahwa ia sebagai anak orang lain ke dalam keluarganya. Ia diperlakukan sebagai anak dalam segi kecintaan, pemberian nafkah, pendidikan dan pelayanan dalam segala kebuuhannya, bukan diperlakukan sebagai anak kandungnya sendiri.

2. Pengertian yang difahamkan dari perkataan tabanni (mengangkat anak secara mutlak) menurut hukum adat dan tradisi yang berlaku pada manusia, yaitu memasukkan anak yang diketahuinya sebagai anak orang lain kedalam keluarganya yang tidak ada hubungan pertalian nasab kepada dirinya sebagai anak yang sah, kemudian ia mempunyai hak dan kewajiban sebagai anak. ${ }^{3}$

Di dalam kedua pengertian tersebut, pengertian nomor pertama yang diungkapkan Mạ̣mud Syaltụt di atas yang sesuai dengan perspektif hukum Islam, karena anak angkat mendapatkan perlakuan yang sama dengan anak kandung dari sisi kasih sayang dan pemenuhan kebutuhan kehidupannya. Sedangkan yang nomor dua tidak dapat diterima karena menyamakan anak angkat secara mutlak sama dengan anak kandung,

${ }^{1}$ Asmuni dan Nispul Khoiri, Fiqh Kontemporer, Dalam Ragam Aspek Hukum (Medan: Wal Ashri Publishing, 2017), hal. 106.

${ }^{2}$ Purwadarminta, Kamus Bahasa Indonesia (Jakarta: Balai Pustaka, 1976), hal. 38.

${ }^{3}$ Mahmud Syaltut, Al-Fatawa, Cet.3, (Kairo : Dār al Qalam, tt), h. 321. 
dalam hak dan kewajibannya seperti mendapatkan warisan dan perwalian saat akan menikah.

\section{Landasan Dalil Tentang Anak Angkat di Dalam Islam}

Pengangkatan anak sudah ada semenjak zaman jahiliyah di Jazirah Arab, sekitar kota Mekah dan Madinah. Kebiasaan ini terus berlanjut hingga kedatangan Islam. Bahkan Rasulullah saw sendiri mempunya anak angkat yang bernama zaid bin Harisah. Artinya mengangkat anak orang lain untuk dijadikan anak angkatnya, yang diasuh seperti anak kandungnya sendiri dengan memenuhi seluruh kebutuhan kehidupannya baik pendidikan maupun pakaian dan lain sebagainya, bukanlah sesuatu yang terlarang dan diharamkan oleh ajaran Islam.

Ada beberapa ayat yang menjelaskan tentang permasalahan anak angkat. Di antaranya adalah yang tercantum di dalam Alquran Surah Al$A h z \bar{a} b$ ayat 4-5:

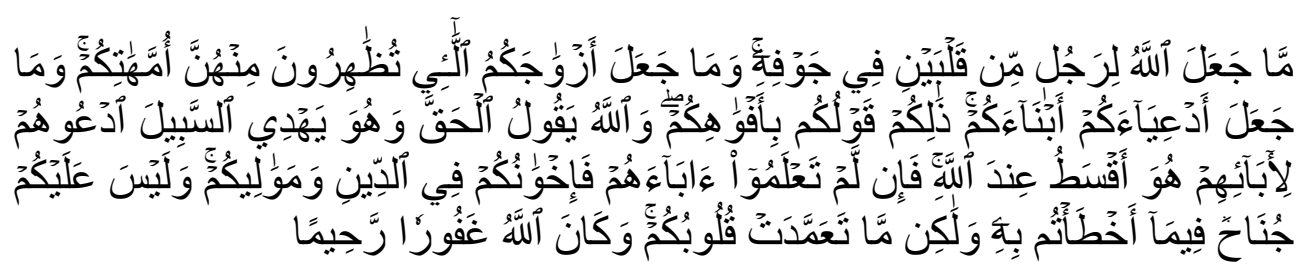

Artinya : "Allah sekali-kali tidak menjadikan bagi seseorang dua buah hati dalam rongganya; dan Dia tidak menjadikan istri-istrimu yang kamu zhihar itu sebagai ibumu, dan Dia tidak menjadikan anak-anak angkatmu sebagai anak kandungmu (sendiri). Yang demikian itu hanyalah perkataanmu di mulutmu saja. Dan Allah mengatakan yang sebenarnya dan Dia menunjukkan jalan (yang benar). Panggilah mereka (anak-anak angkat itu) dengan (memakai) nama bapak-bapak mereka; itulah yang lebih adil pada sisi Allah, dan jika kamu tidak mengetahui bapak-bapak mereka, maka (panggilah mereka sebagai) saudarasaudaramu seagama dan maula-maulamu. Dan tidak ada dosa atasmu terhadap apa yang kamu khilaf padanya, tetapi (yang ada dosanya) apa yang disengaja oleh hatimu. Dan adalah Allah Maha Pengampun lagi Maha Penyayang.

Pada masa jahiliyyah, nasab ayah kandung menjadi hilang digantikan oleh ayah angkatnya. Mereka dikenal dan dipanggil dengan menisbahkan kepada ayah kandungnya. Zaid bin Harisah sendiri pernah beberapa saat dikenal dan dipanggil sebagai Zain bin Muhammad, baru setelah turunnya ayat ini dia kembali dikenal dan dipanggil sebagai Zaid Bin Harisah.

Ayat yang kedua adalah menjelaskan tentang kebolehan isteri anak angkat untuk dinikahi oleh ayah angkatnya, seperti yang tercantum di dalam surah al-Ahzab ayat 37: 


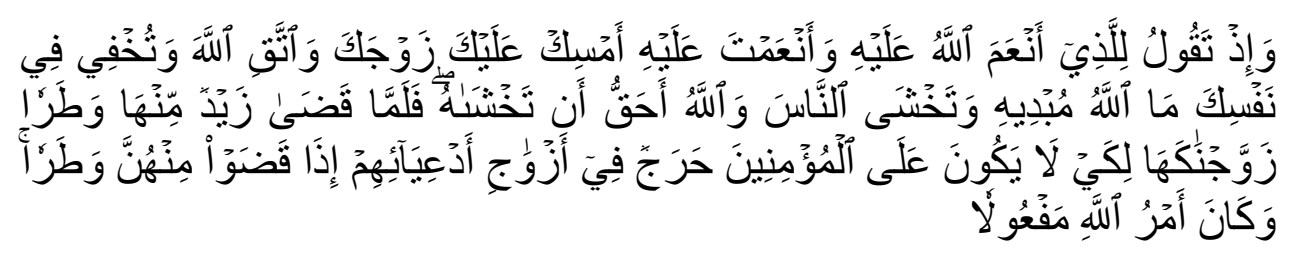

"Dan (ingatlah), ketika kamu berkata kepada orangyang Allah telah melimpahkan nikmat kepadanya dan kamu (juga) telah memberi nikmat kepadanya: "Tahanlah terus isterimu dan bertakwalah kepada Allah", sedang kamu menyembunyikan di dalam hatimu apa yang Allah akan menyatakannya, dan kamu takut kepada manusia, sedang Allah-lah yang lebih berhak untuk kamu takuti. Maka tatkala Zaid telah mengakhiri keperluan terhadap istrinya (menceraikannya), Kami kawinkan kamu dengan dia supaya tidak ada keberatan bagi orang mukmin untuk (mengawini) isteri-isteri anak-anak angkat mereka, apabila anak-anak angkat itu telah menyelesaikan keperluannya daripada isterinya. Dan adalah ketetapan Allah itu pasti terjadi.

Ayat di atas menceritakan tentang Rasulullah saw., yang menikahi Zainab binti Jahsy yang adalah mantan isteri Zaid bin Harisah yang merupakan anak angkat Rasulullah saw. Ini menegaskan bahwa anak angkat bukanlah Mahram yang haram hukumnya untuk dinikahi, ${ }^{4}$ sebagaimana kedudukan anak kandung. Jika Zaid bin Harisah adalah anak kandung Rasulullah saw, tentu saja isterinya haram untuk dinikahi oleh Rasulullah saw., setelah menikah ba'da dukhul.

Dalil dari hadis Rasulullah saw., tentang pengangkatan anak adalah Pertama, Hadis yang diriwayatkan oleh Imām al-Bukhāri:

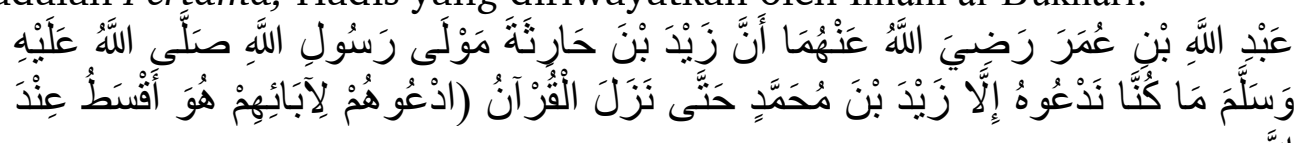

Artinya: "Dari Abdullah bin Umar Radliallahu 'anhuma bahwa Zaid bin Haritsah mantan budak Rasulullah shallallahu 'alaihi wasallam biasa kami panggil dengan Zaid bin Muhammad hingga Allah menurunkan ayat: "Panggillah dia dengan nama bapak-bapaknya, karena hal itu lebih adil di sisi Allah." (H.R Bukhāri:no 4782). ${ }^{5}$

Kedua, Hadis yang diriwayatkan oleh Imām Muslim:

4 Definisi mahram secara bahasa adalah haram untuk menikahinya. Tahịir Aḥmad AzZāwī, Qämūs Al-Muhịt (Riyadh :Dār 'Alim Al-Kutub Thn; 1996 M), hal. 628. Adapun secara istilah adalah orang yang tidak boleh dinikahi selamanya, baik karena hubungan kekerabatan atau persusuan.Ibnu Abidin, Hāsiyah Dār Al-Mukhtar 'Ala Dār Al-Mukhtar(Beirut : Dār Al-Fikr Thn: 2000 M) vol :2, hal. 464.

${ }^{5}$ Muḥammad bin Ismā'il bin Ibrāḥ̄m bin al Mughīrah bin Bardizbah al-Bukhārì al-ju’fi, Saḥịh al-Bukhärí (Riyadh, Dārussalām, 1997), hal. 1017. 


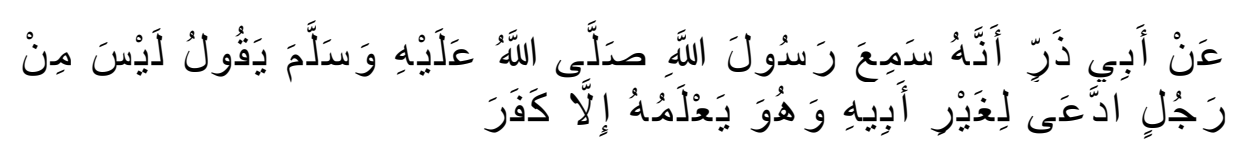

dari [Abu Dzar] bahwa dia mendengar Rasulullah shallallahu 'alaihi wasallam bersabda: "Tidaklah seorang laki-laki yang mengklaim orang lain sebagai bapaknya, padahal ia telah mengetahuinya (bahwa dia bukan bapaknya), maka ia telah kafir. (H.R Muslim, No. Hadis 93).

Ketiga, Hadis yang diriwayatkan oleh Imam Tirmiżì:

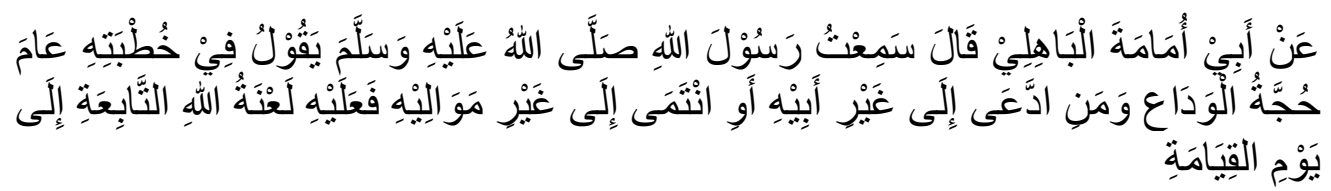

Artinya: "Dari Abu Umamah Al Bahili dia berkata; aku mendengar Rasulullah shallallahu 'alaihi wasallam bersabda di dalam khuthbahnya pada saat haji wada'; barangsiapa yang menasabkan dirinya kepada selain bapaknya, atau berwali kepada selain walinya, maka laknat Allah akan tertimpa atasnya hingga datangnya hari kiamat."(H.R Tirmi $>\mathrm{z} \backslash \mathrm{i}>$ : No. 2120). ${ }^{6}$

Meskipun dibolehkan dan dibenarkan di dalam ajaran Islam, pengangkatan anak dalam perspektif hukum Islam memiliki beberapa permasalahan. Setidaknya ada tiga problematika pengangkatan anak dalam pandangan Islam, di antaranya problem dalam hubungan keluarga, perwalian dan pembagian harta warisan. Sebagaimana yang akan diuraikan berikut ini.

\section{Problematika dalam Hubungan di dalam Keluarga}

Di dalam hubungan keluarga antara anak angkat dengan orang tuanya tidaklah bisa melakukan hubungan seperti anak kandung, karena pada hakikatnya mereka bukanlah mahram antara satu dengan lainnya. Ini berarti bagaimana ketentuan orang asing (ajnabiy) yang ada di dalam hukum islam juga berlaku bagi mereka.

Contoh seperti jika ada seorang lelaki yang mengadopsi seorang perempuan untuk dijadikan anak angkatnya maka saat anak ini dewasa harus menjaga auratnya dari Bapak angkatnya seperti menutup aurat dengan memakai jilbab dan mereka juga dilarang untuk berdua-duaan di rumah saja, ditinggal tanpa ada orang lain, sama seperti ketidak bolehan (ikhtilat) antara lelaki dan perempuan ajnabi. Namun, hal ini dirasa akan sangat sulit karena mereka hidup dalam satu rumah, dan memiliki kedekatan emosional yang kuat, karena telah diasuh dan

\footnotetext{
${ }^{6}$ Muhammad bin 'Isā bin Saurah bin Mūsa bin Ad-Ḍaḥhāk at-Tirmịżi, Jami' AtTirmīżi (Riyadh, Dārussalam, tahun 1999 M), hal. 486.
} 
dirawat sebagaimana layaknya anak kandung, sehingga dianggap wajar saja jika mereka beduaan di rumah atau pergi kemana saja berdua.

Banyak kasus yang terjadi seorang Ayah yang menikahi anak angkatnya, dengan meceraikan isterinya, yang merupakan ibu angkat dari anak perempuan tersebut. Maka, hal semacam ini harus juga menjadi pertimbangan bagi para orang tua yang berniat untuk mengadopsi anak, bahwa ada beberapa hukum Islam yang harus diperhatikan tentang pergaulan antara ayah angkat dengan anak perempuannya adalah seperti hubungan antara ayah tersebut dengan para perempuan lainnya yang tidak memiliki hubungan nasab atau darah selayaknya anak kandung.

Kedekatan emosional, kasih sayang dan cinta antara Ayah dan anak angkatnya, tidaklah membuat hubungan keduanya seperti layaknya ayah dan anak kandung. Dalam perspektif hukum Islam (fikih), Ayah angkat juga boleh menikahi isteri anak Angkatnya. Seperti yang tertuang di dalam Alquran ayat al-Ahzab ayat 37 di atas.

Ayah angkat juga tidak boleh menjadi wali bagi pernikahan anak angkatnya, bila anak angkat tersebut tidak ada hubungan darah atau hubungan keluarga dari ayah angkatnya, yang tidak memungkinkannya untuk menjadi wali. Banyak sekali dalam realitas di masyarakat, anak angkat yang tidak memiliki hubungan darah dimasukkan di dalam Kartu Keluarga dan ditulis sebagai anak kandung, sehingga dianggap oleh Kantor Urusan Agama ayah kandung dan akan menjadi Wali nikahnya. Hal ini mestilah dihindari agar pernikahan tidak menjadi batal karena dinikahkan oleh wali yang tidak berhak/tidak syah. ${ }^{7}$

\section{Problematika Warisan Bagi Anak Angkat}

Anak angkat tidaklah sama dengan anak kandung dalam kedudukannya tentang masalah hak pewarisan dari harta orang tua angkatnya. Dalam hukum Islam anak angkat tidak memiliki hak untuk mendapatkan harta warisan dan juga tidak dapat memberikan warisan kepada orang tuanya. Inilah ketentuan hukum Islam pada hukum asalnya. Pada masa jahiliyyah anak angkat seperti anak kandung dalam hal keberhakan di dalam mendapatkan harta warisan.

Namun dirasa akan cukup kurang bijak dan adil jika anak angkat yang telah memiliki hubungan emosional yang kuat dengan orang tua angkatnya, dan mungkin telah hidup bersama membagi suka dan duka puluhan Tahun dengan mereka tidak mendapatkan hak mendapatkan

7 Wawancara dengan Ali Wardana, Kepala KUA Kecamatan Barus Kabupaten Tapanuli Tengah, pada tanggal 13 Maret 2020. Terkadang ada Ayah angkat yang ingin memaksakan diri untuk menjadi wali putri angkatnya, karena berhak menikahkannya disebabkan sejak bayi sudah diasuhnya. Hal ini juga pengalaman penulis pribadi saat mengikuti pelatihan tentang kepenghuluan salah seorang pembicara menyampaikan kasus yang hampir sama. 
harta dari orang tua angkatnya. Biasanya orang yang mengangkat anak, sedikit banyak akan memiliki kelebihan harta yang dapat diberikan kepada anak angkatnya.

Di antara yang menjadi sebab seorang bisa mewarisi harta warisan dari orang yang meninggal adalah sebagai berikut;

1. Nikah. Pernikahan menjadi penyebab seseorang mendapatkan harta warisan seperti seorang isteri yang medapatkan harta warisan dari suaminya.

2. Nasab, yaitu hubungan antara dua orang yang disebabkan satu kelahiran, yang berjarak dekat atau jauh.

3. Wala', yaitu seseorang yang mempunyai budak, Kemudian ia merdekakan. Ketika budak yang sudah merdeka tadi meninggal, maka ia mendapatkan bagian dari harta warisan dari mantan budaknya tadi. Ataupun orang lain yang memerdekakan seorang budak bukan miliknya, maka ketika budak tersebut meninggal, maka orang yang memerdekakan tadi berhak mendapat warisan dari harta si budak. .

Adapun yang menjadi penghalang seorang ahli waris mendapatkan warisan adalah: pertama, perbudakan, yaitu jika seorang tuan meninggal, maka budaknya tidak bisa mewarisi harta tuannya, karena ia masih menjadi budak. Kedua, pembunuhan. Orang yang membunuh seseorang maka dia tidak akan pernah mendapatkan harta warisan dari orang yang dibunuhnya. Misalkan seorang anak yang membunuh dengan sengaja orang tuanya, maka anak tersebut tidak akan mendapatkan harta warisan dari orang tuanya. Padahal yang tadi seharusnya dia mendapat warisan, maka dia menjadi tidak berhak karena pembunuhan yang dilakukaknya. Sebagaimana hadits Rasulullah:

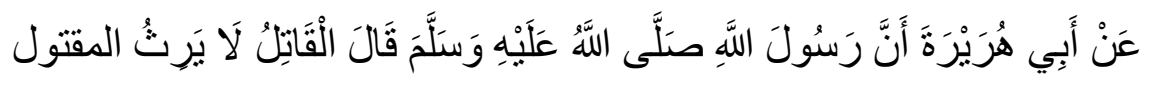

Dari Abu Hurairah, sesungguhnya Rasulullah shallallahu 'alaihi wasallam bersabda: "Pembunuh tidak berhak mendapatkan harta warisan. " (HR. Ibnu Majah:2735) ${ }^{9}$

Ketiga, perbedaan Agama/orang kafir tidak bisa mewarisi harta orang Islam, atau orang Islam tidak bisa mewarisi harta orang kafir ${ }^{10}$

Dari keterangan di atas, dari orang yang berhak mendapatkan harta warisan dan penghalang untuk mendapatkan warisan, maka dapat disimpulkan anak angkat tidak dapat mewarisi harta orang tua angkatnya, karena tidak ada alasan dia untuk mendapatkan harta

\footnotetext{
${ }^{8}$ Muḥammad bin Șāliḥ al-Us̉aimīn, Talkhiṣ Fiqh Al-Farāị̣ (Mesir: Dār al-waṭn, 1423 H), hal. 6. Versi Maktabah Syamila.

9 Muhammad bin Yazìd Bin Majah Al-Qazwini, Sunan Ibnu Majah (Riyadh: Darussalam, 1999), hal. 394.

${ }^{10}$ Muḥammad bin Șālih al-U‘saimīn, Talkhiṣ Fiqh Al-Farāị̣, hal. 24.
} 
warisan dari ketiga alasan yang disebutkan di atas. Dikarenakan tidak ada hubungan nasab, antara dirinya dengan orang tua angkatnya. Maka solusinya adalah bisa dengan hibah atau wasiat. Wasiat yang tidak melebihi dari sepertiga harta warisan si mayit, jika si mayit memiliki ahli waris. ${ }^{11}$

Di dalam menjawab persoalah ini terdapat beberapa pasal dalam Kompilasi Hukum Islam yang berusaha untuk memberikan solusinya bagi pembagian harta Ayah angkat bagi anak angkatnya, dengan jalur wasiat. Di dalam KHI (Kompilasi Hukum Islam) dijelaskan bahwa anak angkat berhak menerima wasiat yang ada kaitannya dengan harta peninggalan orang tua angkatnya, begitu juga sebaliknya orang tua angkat berhak mendapatkan wasiat dari anak angkatnya. Sebagaimana diatur dalam pasal 209 Kompilasi Hukum Islam yang berbunyi:

1. Harta peninggalan anak angkat dibagi berdasarkan Pasal 176 sampai dengan Pasal 193 tersebut di atas, sedangkan terhadap orang tua angkat yang tidak menerima wasiat diberi wasiat wajibah sebanyak-banyaknya $1 / 3$ dari harta wasiat anak angkatnya.

2. Terhadap anak angkat yang tidak menerima wasiat diberi wasiat wajibah sebanyak-banyaknya $1 / 3$ dari harta warisan orang tua angkatnya.

Pengertian "wasiat wajibah" adalah wasiat yang wajib dilakukan untuk kerabat-kerabat terdekat yang tidak mendapat harta pusaka. ${ }^{12}$ Atas dasar realita diatas, KHI yang merupakan buku hukum bagi masyarakat Islam Indonesia, bersikap aspiratis terhadap nasib anak angkat dan orang tua angkat yang tidak menerima wasiat, dalam hal penerimaan harta warisan dengan wujud wasiat wajibah.

Wasiat wajibah tersebut, bukan dimaksudkan sebagai warisan tetapi merupakan wasiat yang diambilkan dari harta peninggalan si mayat yang dalam hal pelaksanaannya tidak tergantung pada persetujuan si mayat. Jadi walaupun anak angkat tidak mendapatkan warisan dan wasiat dari si mayat ketika masih hidup, mereka akan tetap mendapatkan harta peninggalan tidak melebihi $1 / 3$ dari harta si mayat dengan jalan wasiat wajibah. Wasiat wajibah yang dimaksud diatas adalah tindakan yang dilakukan oleh hakim sebagai aparat negara untuk memaksa memberi putusan wajib wasiat bagi orang yang telah meninggal dunia yang diberikan kepada beberapa pihak termasuk juga anak angkat.

\footnotetext{
${ }^{11}$ Wahbah Zuhaili, Fiqhul Islām Wa Adillatuhu (Damaskus, Dar Al-Fikr, 2008), vol. 8, hlm: 57.

${ }^{12}$ M. Hasbi Ash Shiddieqy, Fiqh Mawaris (Semarang: PT. Pustaka Rizki Putra, 1997), hal. 300.
} 


\section{D.Analisis Maqāṣsid asy-syarī'ah terhadap Problematika Anak Angkat}

Maqāsid asy-syaríah, dalam pandangan asy-Sya $>\mathrm{t}\} \mathrm{ibi}>$ adalah tujuan diberlakukannya hukum syariah adalah demi untuk kemaslahatan manusia, baik di dunia maupun di akhirat. ${ }^{13}$ Maqāsid asysyari' 'ah yang dikembangkan asy-Syātibi dibagi menjadi tiga aspek, yaitu bersifat darüriyyah (keharusan), häjiyyah (kebutuhan), dan tahsimizyah (penghiasan). Maqāssid asy-syarī'ah disebut harus karena Maqāṣid ini tidak bisa dihindarkan dalam menopang maslahah ad-din (agama dan akhirat) dan dunia, dengan pengertian bahwa jika mas\}lah\}ah ini dirusak maka stabilitas kehidupan dunia pun menjadi rusak. Kerusakan mas\}lah\}ah ini mengakibatkan berakhirnya kehidupan dunia ini dan diakhirat ia mengakibatkan hilangnya keselamatan dan rahmat.

Berpijak pada permaslahan maslahah ad- darüriyyah, disusunlah kategorinya dalam lima hal, yaitu menjaga kemaslahatan agama (ad-din), jiwa (an-nafs), keturunan (an-nasl), kekayaan (al-māl) dan intelektual (al-'aql). ${ }^{14}$ Kajian tentang permasalahan anak angkat dalam perspektif hukum Islam dalam tulisan ini dikaji dengan menggunakan setidaknya dari kelima kategori maṣlaḥah aḍ-ḍarüriyyah yang disusun oleh Imām Syātịibì di atas.

Tinjauan pertama adalah dari sisi penjagaan agama. Saat adanya perjanjian terhadap pengangkatan anak ini hendaknya dijamin bahwa orang tua angkatnya adalah orang yang seagama jangan sampai ayah angkatnya adalah orang yang beda agama. Jika sudah dipastikan orang tua angkatnya adalah orang yang beragama Islam, maka diusahakan yang akan mengadopsinya adalah orang yang memiliki pemahaman dan pengamalan yang baik terhadap agama sehingga pemeliharaan anak angkat dari sisi agamanya daapt terjamin.

Pengangkatan anak ini ditinjau dari kemashlahatan penjagaan jiwa atau diri sangatlah baik. Karena dari sisi anak yang diangkat, biasanya dari kalangan keluarga yang tidak mampu. Banyak sekali dalam realitas yang terjadi, anak yang diangkat adalah mereka yang dilahirkan di rumah sakit, lalu pihak keluarganya tidak mampu untuk menebus biaya persalinan. Maka, saat ada orang kaya yang mampu membayar biaya persalinan dan kebetulan berkeinginan untuk mengangkat anak, karena dia tidak mempunyai anak, maka dia pun menebus biaya persalinan dengan perjanjian anak tersebut diikhlaskan untuk menjadi anak angkatnya. Banyak juga contoh lainnya dalam kehidupan nyata bahwa anak yang diangkat adalah berasal dari keluarga yang tidak mampu. Jika, dia berasal dari keluarga yang mampu biasanya anak tersebut

${ }^{13}$ Abū Ishāạ Ibrāḥīm al-Lakhmi al-Qirnati Asy-Syāṭibi, Al-Muwāfaqat fi Ușūl al-Aḥkām, Cet III, Jilid II, (Beirut: Dằr al-Ma'rifah, 1997), hal. 324.

${ }^{14}$ Ibid. 
memiliki hubungan persaudaraan dengan orang tua angkatnya, seperti keponakannya dan lain sebagainya. Dari sisi orang tua yang diangkatnya pun mendapatkan kemashlahatan karena ke depannya orang tua akan mendapatkan perhatian dari anak angkatnya saat menua, terlebih bagi mereka yang memang tidak mempunyai anak kandung. Biasanya ikatan emosianal anak angkat terjalin kuat selayaknya anak kandung.

Uraian tentang kemashlahatan penjagaan jiwa di atas berkaitan dengan kemashlahatan penjagaan harta (hifz al-Mäl) dan penjagaan akal (hifz al-'Aql). Orang kaya yang membiayai anak angkat untuk kehidupan dan pendidikannya akan mendapatkan manfaat dari hartanya tersebut, karena digunakan dalam jalan kebaikan membantu orang yang kesusahan. Anak angkat yang miskin menjadi terbantu karena terpenuhi kebutuhan kehidupan dan pendidikannya. Seorang anak yang telah terjamin kebutuhan kehidupan dan pendidikannya, maka maqashid syariah dari sisi penjagaan akalnya (hifz al-'Aql) telah tercapai. Dia mendapatkan jaminan bagi perkembangan wawasan dan pengetahuannya, karena terhindar dari putus sekolah akibat diangkat oleh orang tua yang mampu secara ekonomi. Jaminan ini diharapkan akan berpengaruh bagi perkembangan yang baik bagi jasmani, psikologi dan akhlaknya.

Anak angkat tersebut juga akan mendapatkan dan memiliki harta, karena ke depannya akan mendapatkan bagian dari kekayaan orang tua angkatnya. Kekayaan orang tua angkat menjadi terjaga karena ada anak angkat yang akan menanggung pemeliharaannya saat dia menua dan tidak sanggup lagi mengelolanya. Anak angkat juga akan dapat membantu untuk membelanjakan hartanya saat dia memerlukan bantuan untuk perobatan dan penopang dalam kehidupan masa tuanya. Ada simbiosis mutualisme, kebutuhan, keuntungan dan kebermanfaatan dari kedua belah pihak antara ayah dan anak angkatnya atas harta yang dimiliki.

Terakhir yang perlu diperhatikan adalah penjagaan terhadap nasab (hifz al-Nasl). Anak angkat, seperti pada uraian di atas, tidak boleh dinasabkan kepada orang tua angkatnya, haruslah dinasabkan tetap kepada orang tua kandungnya. Jangan sampai ayah angkat memaksakan diri untuk mendaftarkan dan membuat anak angkat seoalah-olah adalah ayah kandungnya, dan ini akan merusak garis keturunan. Hal ini tentu saja bertentangan dengan konsep maqāsid asysyarī'ah dari penjagaan keturunan. Maqāṣid dari sisi ini akan tetap terjamin selama anak angkatnya tetap dinisbahkan kepada ayah kandungnya. Karena itu, dari sisi ayah angkat tentu tidak terlalu berpengaruh bagi pelanjutan keturunannya, karena anak angkat dilarang untuk dinisbahkan kepada orang tua angkatnya. Dia hanya dapat mencurahkan kasih sayang dan cinta kepada anak angkatnya tersebut seperti anak kandungnya, sebagaimana yang juga dia harapkan 
untuk mendapatkan perlakuan yang sama saat dia telah menua dan butuh pertolongan anak angkatnya. 


\section{E. Kesimpulan}

Pengangkatan anak/pengadopsian anak yang dalam Islam disebut dengan tabanni telah terjadi sejak zaman jahiliyah, dan awal Islam. Pada masa itu, anak angkat kedudukannya disamakan dengan anak kandung tanpa ada perbedaan seperti penisbahan kepada ayah angkatnya dan mendapatkan harta warisan. Saat itu Rasulullah sendiri mempraktekkannya, dengan mengangkat Zaid bin Harisah sebagai anak angkatnya.

Adapun ketika seseorang ingin mengangkat seorang anak, baik karena motif ingin membantu orang lain yang anaknya banyak, sedangkan ekonomi tidak seimbang atau karena motif belum dikaruniai oleh Allah seorang anak, maka ini diperbolehkan oleh syariat, bahkan dianjurkan. Yang terpenting adalah anak tersebut harus tetap dinasabkan kepada orang tua kandungnya, bukan ayah angkatnya sesuai dengan firman Allah swt di dalam Alquran surah al-Ahzab ayat 4-5.

Pengangkatan anak dari analisis maqāsid asy-syarī ah dapat menjamin bagi penjagaan jiwa, agama, harta, akal dan nasab, jika mematuhi pedoman dan panduan yang telah digariskan oleh ajaran Islam. Perhatian penting dalam analisis ini adalah pada penjagaan keturunan, di mana ditekankan secara kuat dalam Islam bahwa anak angkat tidak boleh untuk dinisbahkan kepada ayah angkatnya tetapi tetap kepada ayah kandungnya, agar pelanjutan nasab tidak menjadi samar dan rusak. Hal ini dalam realitas kehidupan nyata, terkadang diabaikan oleh orang tua angkat dengan meletakkan saja namanya sebagai ayah kandung di kartu keluarga.

\section{DAFTAR PUSTAKA}

'Abidin, Ibnu. Hāsiyah Dār Al-Mukhtar 'Ala Dār Al-Mukhtar. Beirut : Dār Al-Fikr Thn: $2000 \mathrm{M}$.

al-Bukhārī, Muḥammad bin Ismā‘il bin Ibrāhīm bin al Mugìrah bin Bardizbah. Șahịḥ Bukhârì. Riyadh, Darussalām thn: 1997.

Al-Qazwini, Muhammad Bin Yazīd Bin Majāh. Sunan Ibnu Majāh. Riyadh: Darussalam, 1999.

Al-Usaimīn, Muhammad bin Ṣāliḥ. Talkhiṣ Fiqh Al-Farāị̣. Mesir: Dār al-waṭn, $1423 \mathrm{H}$. 
Ash Shiddieqy, M. Hasbi. Fiqh Mawaris. Semarang: PT. Pustaka Rizki Putra, 1997.

Asmuni, dan Nispul Khoiri. Fiqh Kontemporer, Dalam Ragam Aspek Hukum. Medan: Wal Ashri Publishing, 2017.

Asy-Syạtịibì, Abū Isḥāq Ibrāhīm al-Lakhmi al-Qirnati. Al-Muwāfaqat fî̀ Uṣūl alAḥkām. Cet III, Jilid II. Beirut: Dār al-Ma'rifah, 1997.

at-Tỉrmìiżi, Muḥammad bin 'Isā bin Saurah bin Mūsā bin ad-Daḥḥak. Jami' atTirmizizi. Riyadh: Darussalam, tahun 1999.

Az-Zāwìi, Ṭahị Aḥmad Qāmūs Al-Muhịṭ. Riyadh :Dār ‘Alim Al-Kutub Thn; 1996 M.

Maḥmūd Syalțūt. Al-Fātawā, Cet.3. Kairo : Dār al Qalām, tt.

Purwadarminta. Kamus Bahasa Indonesia. Jakarta : Balai Pustaka, 1976.

Zuhaili, Wahbah. Fiqhul Islām Wa Adillatuhu. Damaskus: Dār Al-Fikr, 2008. vol. 8 . 